\title{
The Response of Native Vertebrate Popu- lations to Crested Wheatgrass Planting and Grazing by Sheep
}

\author{
TIMOTHY D. REYNOLDS AND CHARLES H. TROST
}

\begin{abstract}
Native vertebrate population levels were examined in grazed and ungrazed habitats dominated by big sagebrush (Artemisia tridentata) and crested wheatgrass (Agropyron cristatum) in southeast Idaho. Our objective was to determine the species diversity and relative density of birds, mammals, and reptiles in these habitats with and without grazing pressures by sheep. In a habitat dominated by sagebrush, grazing did not significantly alter the species diversity or the density of reptiles or nesting birds. However, both the diversity and the relative density of small mammals were significantly reduced. Crested wheatgrass plantings, regardless of sheep use, supported fewer nesting bird species and a lower density of birds, mammals, and reptiles than did areas dominated by sagebrush. The synergistic effects of planting with crested wheatgrass followed by grazing were most evident in (1) a significant reduction in the relative density of small mammals, and (2) the occurrence of only one nesting bird species: the horned lark (Eremophila alpestris).
\end{abstract}

At one time over 100 million ha of the western rangelands in the United States were covered with sagebrush, mostly big sagebrush (Artemisia tridentata) (Beetle 1960). Historically, the primary use of sagebrush rangeland has been for livestock grazing. Many areas formerly dominated by sagebrush have been burned, chained, disced, plowed, or sprayed and reseeded with grasses to improve forage for livestock. Additionally, crested wheatgrass (Agropyron cristatum) is being planted in the Intermountain West in an attempt to reclaim strip-mined lands. Braun et al. (1976) estimated that a minimum of $10 \%$ of the native sagebrush vegetation in western U.S. has been treated in one way or another. In Idaho alone, 650 thousand ha of public land (BLM document 1974) and 200 thousand ha of private land (L. Sharp, pers. comm.), mostly dominated by sagebrush, have been reseeded with crested wheatgrass. Until recently, little concern was expressed about the potential effects of alteration of sagebrush range on wild animals. The objective of this study was to determine the response of native vertebrate populations (birds, mammals, and reptiles) to different land use practices on the Idaho National Engineering Laboratory (INEL) Site.

\section{Study Areas}

The INEL Site, located approximately $48 \mathrm{~km}$ west of Idaho Falls, Ida., is a nuclear reactor test facility administered by the U.S.

Authors are with the Department of Biology, Idaho State University, Pocatello. 82309. Reynolds at present is with Environmental Sciences Branch, Department of Energy, 550 2nd St., Idaho Falls, Idaho 83401.

Manuscript received December 1, 1978.
Department of Energy. In 1975 the 2,315- $\mathrm{km}^{2}$ site was designated as a National Environmental Research Park. As such, stringent controls have been placed on the alteration of habitat and the harassment of wildlife. A notable exception to this is that sheep and cattle are allowed to graze the periphery of the Site, and in those grazed areas predator control is permitted. The climate, topography, and vegetation of the INEL Site are representative of the Upper Great Basin and are characterized by hot summers and cold winters, flat to gently rolling landscape, with big sagebrush as the dominant vegetation.

Four areas of different land treatment were selected for study. Two of these were dominated by big sagebrush, and two were former sagebrush range reseeded with crested wheatgrass. One sagebrush and one crested wheatgrass study area were located just within the southern boundary of the INEL Site. These two areas, each covering over $100 \mathrm{~km}^{2}$, were contiguous and were a portion of a grazing allotment used by 1,000-1,200 sheep each spring since 1960. The crested wheatgrass here was planted in 1958 or 1959 (INEL Site records vary) after disc removal of the native sagebrush. These areas will be referred to as Grazed Sage and Grazed $C W G$. The other two study areas were approximately 12 $\mathrm{km}$ northwest of the grazed areas, within that portion of the Site protected from grazing. The sagebrush here (Ungrazed Sage) was periodically grazed prior to 1950 but had no domestic livestock on it for over a quarter of a century. This was the control area for the study. The adjacent crested wheatgrass habitat (Ungrazed CWG) was planted in the summer of 1960, after winter flooding inundated and killed the native sagebrush (A. Olson, pers. comm.). Livestock have never been permitted in this reseeded area.

\section{Materials and Methods}

Detailed descriptions of the materials and methods used in this study can be found in Reynolds (1978). Briefly, the vegetation in each study area was sampled at 160 sampling points with $0.1 \mathrm{~m}^{2}$ sampling frames. The number of plots in which a species occurred (frequency) and the estimated canopy coverage (Daubenmire 1959) were recorded for each plant species. Data concerning birds and large mammals were gathered via visual observation. This information was the result of equal time spent in a 4-ha grid in each of the study areas. Small mammals were sampled using Museum Special snap traps set in a Type-A trap line (Calhoun 1959). One-hundred and twenty snap traps were set concurrently in all four study areas for three nights each month from January 1976 through February 1977. The traps were moved each sampling period to ensure that population densities, rather than recruitment levels, were being measured. Reptiles were sampled by a series of pitfall traps in a 4-ha grid system with the traps at 50-m intervals. All reptiles collected in the traps, and those captured within the study areas by hand or with a noose, were marked with indelible ink for individual identification. For all taxa, the number of individuals encountered and/or collected in any study was 
considered to be an indication of the relative density of that particular species in that habitat. Differences in the relative densities were tested with the Chi Square test (Sokal and Rohlf 1969). A species diversity index was calculated independently for vegetation, birds, and mammals using the transformation of the Shannon-Weiner function (7ar 1974):

$$
H=\frac{n \log n-\Sigma f \log f}{n}
$$

where $f$ was the frequency of each species and $n$ was the total frequency of occurrence of all species. Differences in species diversity were compared with the $t$-test developed by Hutcheson (1970). The level of significance for all statistical tests was $P<0.05$.

\section{Results}

\section{Vegetation}

The control area (Ungrazed Sage) contained 31 plant species (Table 1) and had a species diversity index $(\mathrm{H})$ of 2.85. This was significantly higher than all other study areas. Big sagebrush occurred in $66 \%$ of the sampling plots in the control area and accounted for $41 \%$ of the total canopy coverage. The Grazed Sage contained only 9 species of plants (Table 1). Here sagebrush was found in $71 \%$ of the sampling plots and provided $65 \%$ of the total canopy cover. Crested wheatgrass was found in all 160 sampling plots in the Ungrazed $C W G$ and in 154 plots (96\%) in the Grazed $C W G$, providing $98 \%$ and $89 \%$ of the total canopy coverage respectively.

Table 1. Percent coverage (\%) and frequency (f) of plant species in grazed and ungrazed habitats dominated by sagebrush (Artemisia tridentata) and by crested wheatgrass (Agropyron cristatum) on the INEL Site. Only those species with frequency of 10 or more, or a percent coverage of at least $1 \%$ are included.

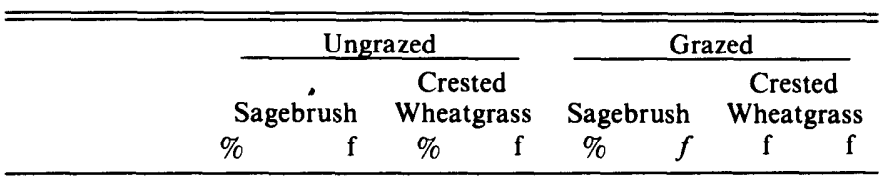

Opuntia polya-

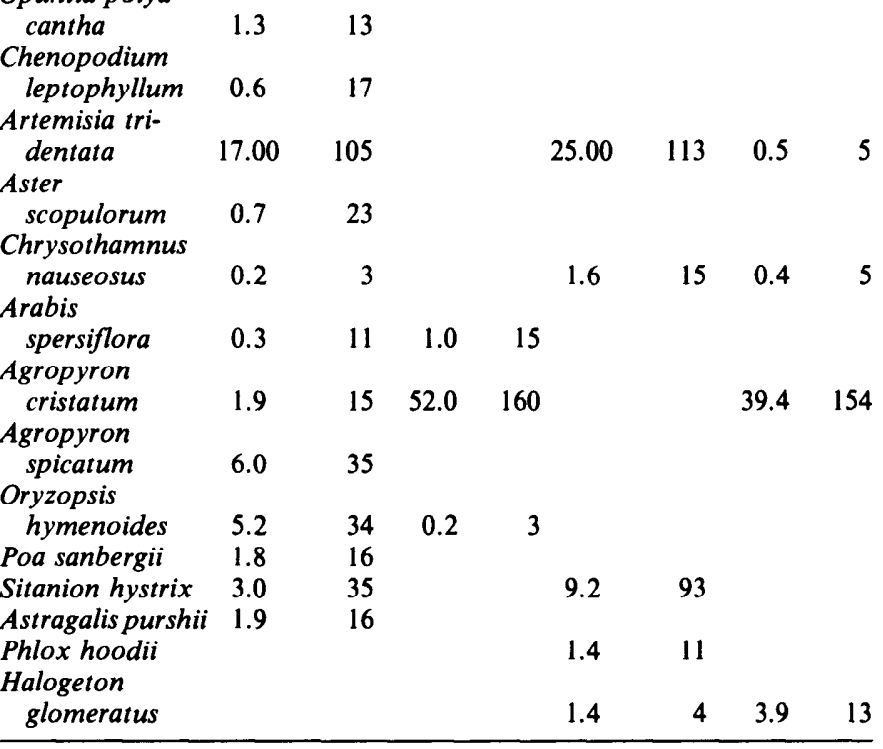

Total numbers of species 31 3

Total \%

coverage

Species diversity
Nesting Birds

A total of 71 bird nests, representing 10 species of bird was found during the study (Table 2). There were $n$ significant differences in either the density or the diversity c birds nesting in the Ungrazed and Grazed Sage habitat Conversely, both crested wheatgrass habitats had significantly lower species diversity and relative density ( nesting birds than both the control areas and the Graze Sage.

Table 2. Number of nests located in grazed and ungrazed habitats dom nated by sagebrush (Artemisia tridentata) and by crested wheatgra: (Agropyron cristatum) on the INEL SIte, 1976 and 1977.

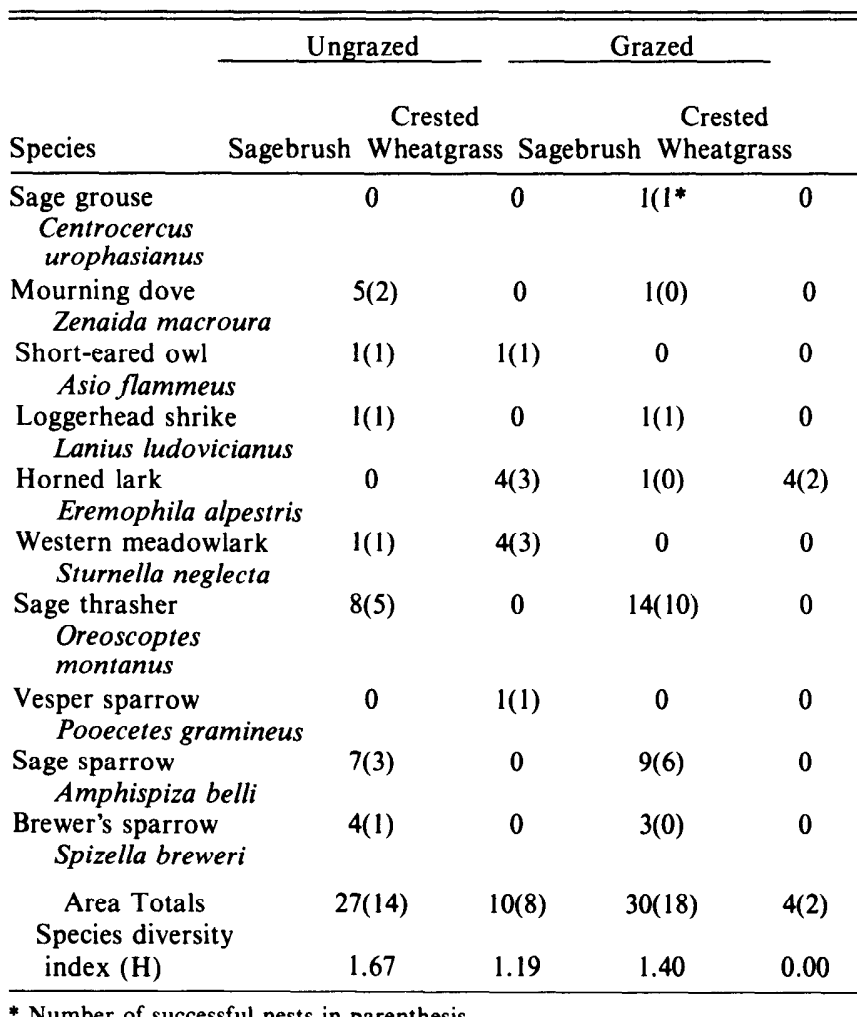

* Number of successful nests in parenthesis.

\section{Small Mammals}

A total of 548 small mammals, representing 9 species $\mathbf{w}$ collected during 20,160 trap nights (Table 3 ). The relati density of small mammals was significantly greater in tl control area than in any other habitat examined. Althoug the Grazed $C W G$ area had a relative density of sme mammals significantly below that in all other study area this was the only area that did not have a species diversi index significantly below that found in the control area.

\section{Large Mammals}

Visual sightings, as a sampling technique, are biased favor of large diurnal animals. Thus, to reduce this bic observations of the pronghorn antelope (Antilocap americana) were not included in the relative density a1 species diversity comparisons for large mammals. $T$ number of large mammals sightings are given in Table The relative density of large mammals was essentially $t$ same between the two habitats dominated by sagebrush, $b$ was significantly below the control in both of the crest wheatgrass areas. This same trend was apparent in $t$ species diversity comparisons. 
Table 3. Small mammals collected by snap traps in grazed and ungrazed habitats dominated by sagebrush (Artemisia tridentata) and be crested wheatgrass (Agropyron cristatum) on the INEL Site, 1976-1977.

\begin{tabular}{|c|c|c|c|c|}
\hline \multirow[b]{3}{*}{ Species } & \multicolumn{4}{|c|}{ Number collected } \\
\hline & \multicolumn{2}{|c|}{ Ungrazed } & \multicolumn{2}{|c|}{ Grazed } \\
\hline & Sagebrush & $\begin{array}{c}\text { Crested } \\
\text { Wheatgrass }\end{array}$ & Sagebrush & $\begin{array}{c}\text { Crested } \\
\text { Wheatgrass }\end{array}$ \\
\hline $\begin{array}{l}\text { Peromyscus } \\
\text { maniculatus }\end{array}$ & 131 & 96 & 130 & 31 \\
\hline $\begin{array}{l}\text { Reithrodontomys } \\
\text { megalotis }\end{array}$ & 11 & 56 & 8 & 2 \\
\hline Eutamias minimus & 1 & 1 & 15 & 0 \\
\hline Onychomys leucogaster & 12 & 1 & 4 & 3 \\
\hline Dipodomys ordii & 2 & 0 & 2 & 5 \\
\hline Citellus townsend & 4 & 0 & 0 & 2 \\
\hline Perognathus parvus & 3 & 2 & 0 & 0 \\
\hline Lagurus curtatus & 2 & 1 & 0 & 0 \\
\hline Microtus montanus & 1 & 1 & 0 & 1 \\
\hline $\begin{array}{l}\text { Total number } \\
\text { collected }\end{array}$ & 187 & 158 & 159 & 44 \\
\hline Number of species & 9 & 7 & 5 & 6 \\
\hline $\begin{array}{l}\text { Species diversity } \\
\text { index }(\mathrm{H})\end{array}$ & 1.11 & 0.85 & 0.69 & 1.04 \\
\hline
\end{tabular}

\section{Reptiles}

Four species of reptiles were encountered during the study. Two of these were serpentine species: the gopher snake (Pituophis melanoleucus) and the Great Basin rattlesnake (Crotalus viridis), which were found only in the grazed study areas (Table 5). Linder and Sehman (1977) state that these two species are common and widespread over the INEL Site. Sehman (1978) further states that the maximum dispersal distance recorded on the Site from a winter hibernaculum is less than $2 \mathrm{~km}$. From this, we must assume that the two ungrazed study areas were greater than $2 \mathrm{~km}$ from a suitable denning site. This indicated a bias in our sampling technique, and serpentine species were therefore eliminated from further analysis.

The lizard data, however, were comparable. Both the Grazed and Ungrazed $C W G$ study areas had a relative density of lizards significantly below that found in the control area, although the diversity of lizards was significantly lower only in the Grazed $C W G$ habitat. There were no statistical differences in either the density or the

Table 4. Number of mammals observed in grazed and ungrazed habitats dominated by sagebrush (Artemisia tridentata) and be crested wheatgrass (Agropyron cristatum) on the INEL Site.

\begin{tabular}{|c|c|c|c|c|}
\hline \multirow[b]{3}{*}{ Species } & \multicolumn{4}{|c|}{ Number of observations } \\
\hline & \multicolumn{2}{|c|}{ Ungrazed } & \multicolumn{2}{|c|}{ Grazed } \\
\hline & Sagebrush & $\begin{array}{c}\text { Crested } \\
\text { Wheatgrass }\end{array}$ & Sagebrush & $\begin{array}{c}\text { Crested } \\
\text { Wheatgrass }\end{array}$ \\
\hline Mustela frenata & 1 & 0 & 0 & 0 \\
\hline Canis latrans & 8 & 9 & 1 & 0 \\
\hline Eutamias minimus & 18 & 0 & 19 & 5 \\
\hline Neotoma cinerea & 1 & 0 & 0 & 0 \\
\hline Citellus townsendi & 1 & 1 & 1 & 5 \\
\hline Lepus californicus & 1 & 0 & 2 & 0 \\
\hline Sylvilagus nuttalli & $i$ & 0 & 2 & 0 \\
\hline Sylvilagus idahoensis & 0 & 0 & $\overline{1}$ & 0 \\
\hline Total registrations & 31 & 10 & 26 & 10 \\
\hline Number of species & 7 & 2 & 6 & 2 \\
\hline Species diversity & & & & \\
\hline index & 1.22 & 0.33 & 1.00 & 0.69 \\
\hline
\end{tabular}

Table 5. Number of reptiles encountered in grazed and ungrazed habitats dominated by sagebrush (Artemisia tridentata) and by crested wheatgrass (Agropyron cristatum) on the INEL Site.

\begin{tabular}{|c|c|c|c|c|}
\hline \multirow[b]{3}{*}{ Species } & \multicolumn{4}{|c|}{ Number encountered } \\
\hline & \multicolumn{2}{|c|}{ Ungrazed } & \multicolumn{2}{|c|}{ Grazed } \\
\hline & Sagebrush & $\begin{array}{c}\text { Crested } \\
\text { Wheatgrass }\end{array}$ & Sagebrush & $\begin{array}{c}\text { Crested } \\
\text { Wheatgrass }\end{array}$ \\
\hline $\begin{array}{l}\text { Short-horned lizard } \\
\text { (Phyrnosoma doug- } \\
\text { lassi) }\end{array}$ & 17 & 4 & 26 & 7 \\
\hline $\begin{array}{l}\text { Sagebrush lizard } \\
\text { (Sceloporus } \\
\text { graciosus) }\end{array}$ & 37 & 5 & 21 & 0 \\
\hline $\begin{array}{l}\text { Gopher snake } \\
\text { (Pituophis melano- } \\
\text { leucus) }\end{array}$ & 0 & 0 & 2 & 0 \\
\hline $\begin{array}{l}\text { Great Basin rattlesnake } \\
\text { (Crotalus viridis) }\end{array}$ & 0 & 0 & 3 & 3 \\
\hline
\end{tabular}

diversity of lizards between the two sagebrush habitats.

\section{Discussion and Conclusions}

Grazing and crested wheatgrass planting significantly reduced the plant species diversity. The Grazed Sage had only $1 / 3$ as many plant species as the control area. This paucity of species richness affected the plant species diversity, but the overall physiognomy of the area remained unchanged. Big sagebrush was still abundant and provided the overstory, while grasses and forbs, albeit few species of each, comprised the understory. As such, the relative density and diversity of nesting birds, large mammals, and lizards were essentially unchanged from the control condition. Insects are the major food source for passerine birds on the Snake River Plain during the summer months, while lizards feed extensively on ants (Guyer 1978). Although the distribution of insect species may be altered by changes in vegetation, the availability of insect prey is not necessarily affected. Active ant mounds are ubiquitous on the Snake River Plain and appear to be as common (or even more so) in grazed habitats as they are in ungrazed areas. Additionally, birds as well as large mammals are highly mobile species, able to move large distances in search of food. Thus, any changes in the vegetation caused by grazing in a habitat dominated by sagebrush apparently did not affect either the food base or the use of the habitat by birds, lizards, or large mammals.

Populations of small mammals were, however, significantly reduced in the Grazed Sage study area. Small mammals are, for the most part, vegetarians, feeding on seeds or herbaceous material. The decrease in the forbs and grasses suitable for rodent forage was most likely responsible for the reduced diversity and density of small mammals in this area.

Planting a former sagebrush range to crested wheatgrass has a more widespread affect on wildlife populations. Not only is the vegetational diversity reduced to a virtual monoculture, but the entire structure of the habitat is altered. Many species of animals that have evolved in a sagebrush habitat are so tightly tied to that habitat that they apparently are unable to colonize other environments. Notably, the Sage Grouse, Sage Thrasher, Sage Sparrow and Brewer's Sparrow are considered to be sagebrush obligates almost entirely dependent on the sagebrush 
environment (Braun et al. 1976). Additionally, the two species of lizards encountered in this study may be similarly linked to the sagebrush habitat (Dumas 1964). Thus, it is not surprising that the study areas dominated by crested wheatgrass contained population densities below those found in the control area for all the vertebrate groups examined. It is of interest to note that although the relative densities of small mammals and lizards in the crested wheatgrass areas were below the control, neither the diversity of reptiles in the Ungrazed $C W G$, nor the diversity of small mammals in the Grazed $C W G$ were significantly altered. We do not believe that this accurately reflects the response of these groups to different land use practices but demonstrates a shortcoming inherent in all diversity indices: unequal response to unequal sample size. There is an inverse relationship between the number of individuals in a sample and the magnitude of the effect the addition or deletion of a species has on the species diversity index. Thus, with only 9 lizards found in the Ungrazed $C W G$, and only 44 mammals trapped in the Grazed CWG, the important aspect is not the quality of the diversity indices, but the actual reduction in the respective populations.

In summary, the alteration of native sagebrush on the INEL Site was accompanied by a differential response of native vertebrate populations to each land management practice. Although small mammal populations were reduced in the Grazed Sage, the planting of crested wheatgrass had a more severe effect on wild animal populations than did grazing by sheep. However, the synergistic effect of both grazing and reseeding resulted in the lowest population levels of all the vertebrate classes examined. Birds seemed to receive the brunt of the synergistic effects. The horned lark (Eremophila alpestris) was the only species found to nest in the area that was both planted and grazed. And, during both years of the study, even though horned larks were nesting in the Ungrazed $C W G$, they did not begin nesting activities in the Grazed $C W G$ until almost 2 weeks after the sheep had been moved to a different range. Thus, physical disturbances, as well as vegetation changes brought about by different land use practices, have an effect on wildlife.

In the Intermountain West we have been fortunate to have a thriving and successful agribusiness without the total loss of good wildlife habitat. However, as the need for more agricultural products increases, and more and more rangeland is altered to meet these needs, we run the risk of seriously reducing, perhaps even losing, the populations of many of our native vertebrate species. We do not advocate that agriculture production be reduced so that a few birds, mammals, and reptiles can survive: but we do feel that with foresight and the proper mitigation measures we can continue to have the best of both worlds. Setting aside portions of the public lands as wilderness or primitive areas would ensure the survival of many species that otherwise may be extirpated by modern agricultural practices. Additionally, these refugia would, like the INEL National Environmental Research Park, serve as a yardstick with which to measure the impacts of land management practices in the future.

\section{Literature Cited}

Beetle, A.A. 1960. A study of sagebrush: The Tridentata of Artemisia. Univ. Wyoming Exp. Sta. Bull. 368, Laramie. 83 p.

Braun, C.E., M.F. Baker, R.L. Eng, J.S. Gashwiler, and M.H. Schroeder, 1976. Conservation committee report on effects of alteration of sagebrush communities on the associated avifauna. Wilson Bull. 88:165171.

Bureau of Land Management. 1974. Idaho Range Management Program Report. p. I-6-I-7.

Calhoun, J.B. 1959. Revised sampling procedures for the North American Census of Small Mammals (NACSM). Population dynamics of vertebrates, Release No. 10. Administrative Publ. U.S. Dep. HEW, PHS, National Institute of Mental Health, Bethesda, Md. 12 p.

Daubenmire, R.F. 1959. A canopy-coverage method of vegetational analysis. Northwest Sci. 33:43-64.

Dumas, P.C. 1964. Species-pair allopatry in the genera Rana and Phrynosoma. Ecology 45:178-181.

Guyer, C. 1978. Comparative ecology of the short-horned lizard (Phrynosoma douglassi) and the sagebrush lizard (Sceloporus graciosus.). MS Thesis, Idaho State Univ., Pocatello 130 p.

Hutcheson, K. 1970. A test for comparing diversities based on the Shannon formula. J. Theoret. Biol. 29:151-154.

Linder, A.D., and R.W. Sehman. 1977. Herpetofauna of the Idaho National Engineering Laboratory Site. J. Idaho Acad. Sci. 13:42-46.

Reynolds, T.D. 1978. The response of native vertebrate populations to different land management practices on the Idaho National Engineering Laboratory Site PhD Diss. Idaho State Univ., Pocatello. 105 p.

Sehman, R.W. 1977. Hibernaclum dynamics of the Great Basin rattlesnake (Crotalus viridis lutosus). MS Thesis. Idaho State Univ., Pocatello, 66 p.

Sokal, R.R., and F.J. Rohlf. 1969. Biometry. W.H. Freeman and Co., San Francisco. $776 \mathrm{p}$.

Zar, J.R. 1974. Biostatistical Analysis. Prentice-Hall, Inc., Englewood Cliffs, N.J. p. 35-36. 